УДК 619:636.4.082:575.1:577.2.

(C) 2014

Ксьонз I. М., доктор ветеринарних наук,

Цівенко Т. М., стариий науковий співробітник,

Почерняєв К. Ф., Корінний С. М., кандидати сільськогосподарських наук

Інститут свинарства і агропромислового виробництва НААН

\title{
РОЗРОБЛЕННЯ ПЛР-ТЕСТ-СИСТЕМИ ДЛЯ ІНДИКАЦІЇ БАКТЕРІЙ РОДУ CHLAMYDIA У БІОЛОГІЧНИХ ЗРАЗКАХ ВІД СВІЙСЬКИХ СОБАК
}

\section{Рецензент - доктор ветеринарних наук, професор П. І. Локес}

Розроблено ПЛР-тест-систему для діагностики хламідіозу свійських собак, до складу якої входять олігонуклеотидні праймери, щзо фланкують ділянку гена, який кодує ендорибонуклеазу P (RNase P RNA) Chlamydia abortus, Chlamydia pecorum, Chlamydia psittaci. Ідентичність продукту ампліфікаиії підтверджено шляхом рестрикційного аналізу з використанням ендонуклеази Alи I. Означена ПЛР-тест-система випробувана на 50-и позитивних $і$ 25-и негативних зразках ДНК бактерій роду Chlamydia, виділених 3 ізолятів хламідій від собак, а також успішно пройшла валідацію із іншими ПЛР-тест-системами для індикації та видової диферениіації збудників хламідійних інфекиій ссавичв і птахів.

Ключові слова: свійські собаки, Chlamydia abortus, Chlamydia pecorum, Chlamydia psittaci, олігонуклеотидні праймери.

Постановка проблеми. Існує усталена думка, що хламідіоз серед собак зустрічається вкрай рідко. Разом із тим, досліджуючи біологічні зразки від тварин цього виду, які хворіли з симптомами кон'юнктивітів, уражень респіраторного та урогенітального трактів, у 46,6 \% було встановлено діагноз на хламідіоз [1].

Досить часто діагноз залишається не встановленим або встановленим несвоєчасно, що призводить до неадекватної терапії й, відповідно, до ускладнення захворювання, що іноді призводить до генералізованої форми. Не слід також забувати, що хламідійна інфекція має зоонозний характер і відомі випадки зараження людей від хворих на хламідіоз собак [2-4].

Аналіз основних досліджень і публікацій, в яких започатковано розв'язання проблеми. Для діагностики хламідіозу собак застосовуються різні лабораторні методи: культуральні, імунологічні, морфологічні та молекулярно-генетичні $[3,5]$. Означені методи відрізняються за специфічністю та чутливістю. За нашим переконанням, наразі найбільш виправданим методом діагностики за хламідійних інфекцій є полімеразна ланцюгова реакція (ПЛР) [5]. Іноземними, зокрема російськими, вченими розроблялись
ПЛР-тест-системи для індикації бактерій роду Chlamydia у біологічних зразках собак, що мають достатню специфічність і чутливість $[2,3]$. Однак, наразі такі діагностикуми не зареєстровані в Україні.

Мета досліджень - розробити надійний високочутливий і високоспецифічний засіб діагностики хламідіозу свійських собак.

Завдання: сконструювати дизайн пари олігонуклеотидних праймерів; підібрати оптимальні параметри реакційної суміші й режиму ампліфікації ПЛР-тест-системи для діагностики хламідіозу свійських собак.

Методика проведення досліджень. За результатами проведеного нами диференціювання за допомогою мультиплексної ПЛР-тест-системи 69 ізолятів хламідій, виділених від свійських собак, 3'ясовано, що етіологічними чинниками хламідіозу є три види бактерій роду Chlamydia, зокрема: Chlamydia abortus, Chlamydia pecorum, Chlamydia psittaci [5]. Саме тому об'єктом для конструювання олігонуклеотидних праймерів у ПЛР-тест-системі для діагностики хламідіозу свійських собак, що розроблялась, обрано ділянку гена, який кодує ендорибонуклеазу P (RNase P RNA) означених трьох видів бактерії роду Chlamydia.

Результати досліджень. Створення дизайну олігонуклеотидних праймерів для визначення хламідійних інфекцій свійських собак у полімеразної ланцюгової реакції передбачало пошук специфічних ділянок гена, який кодує RNase P RNA бактерій Chlamydia abortus, Chlamydia pecorum, Chlamydia psittaci та зручних для електрофоретичної детекції. Для аналізу з бази даних «GenBank» (версія 00.2003 року) були обрані первинні послідовності геномів родини Chlamydia: DQ257295 Chlamydia abortus, AJ012173 Chlamydia pecorum, AJ310737 Chlamydia psittaci.

За допомогою комп'ютерних програм «Virtual Genome Center» (http://alsec/med/umn/edu/VGC.html) та «Fast PCR» було проаналізовано секвеновані послідовності гена, який кодує RNase P RNA, 


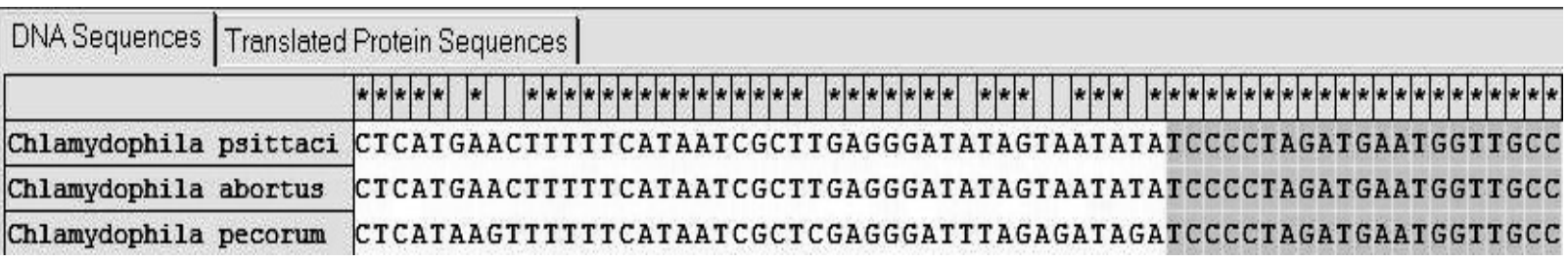

\section{Рис. Цільові та фланкуючі послідовності олігонуклеотидних праймерів гена, щцо кодує RNase P RNA Chlamydia abortus, Chlamydia pecorum, Chlamydia psittaci: а) прямого; б) зворотного (виділено сірим кольором)}

вищезазначених представників роду Chlamydia та одержано пару олігонуклеотидних праймерів: прямий - CHCPF: 5-GGAGAAA CTCCAGG GGCCGT-3 та зворотний - CHCPR: 5'GGCAACCATTCA TCTAGGGGA-3` (див. рис.).

Означена пара олігонуклеотидних праймерів, що фланкує фрагмент гена RNase P RNA Chlamydia abortus, Chlamydia pecorum, Chlamydia psittaci, синтезована за нашим замовленням у компанії «Thermo Electron Corporation» (Germany).

Полімеразну ланцюгову реакцію із застосуванням розроблених нами олігонуклеотидних праймерів, що фланкують гена МОМР хламідій, проводили в поліпропіленових мікроцентрифужних пробірках об'ємом $0,6 \mathrm{~cm}^{3}$ на термоциклері «Терцик-2» виробництва «ДНК-технологии» (Россия) в 25 мкл ПЛР-суміші. Оптимізація умов ПЛР передбачала підбір складу реакційної суміші й температурний режим ампліфікації. Оптимальним складом реакційної суміші $є$ наступні: 2,5 мкл 10 кратного буфера (670 мМ Tpic-HCI, $\mathrm{pH} 8,8$ за температури $25^{\circ} \mathrm{C}, 20$ мМ БСА, $166 \mathrm{мM}$ амонію сірчанокислого (NH4)2SO4, 100 мМ 2- $\beta$ меркаптоетанол), 1 мкл 2,5 mM dNTP, по 0,5 мкл (0,1 опт. один.) кожного 3 праймерів, 1,5 мкл $50 \mathrm{mM} \mathrm{MgCl2}$, зразок ДНК - до кінцевої концентрації в суміші 1 мкг $/ \mathrm{cm}^{3}, 2-3$ од. Таq ДНКполімерази (Thermus aquaticus) (Державний Наyковий Центр Російської Федерації «ГосНИИгенетика, Россия, г. Москва). На ампліфікаційну суміш нашаровували 25 мкл мінеральної олії.

Продуктом ПЛР є фрагмент гену, що кодує RNase P RNA, що має розмір - 253 пари нуклеотидів, характерний для бактерії Chlamydia abortus, Chlamydia pecorum, Chlamydia psittaci. Електрофоретичне розділення продуктів ПЛР у поліакріламідному або агарозному гелі дозволяє чітко визначати наявність ДНК збудника хламі- діозу свійських собак за відповідним розміром ампліфікованого фрагмента. Оптимальні параметри ампліфікації становили:

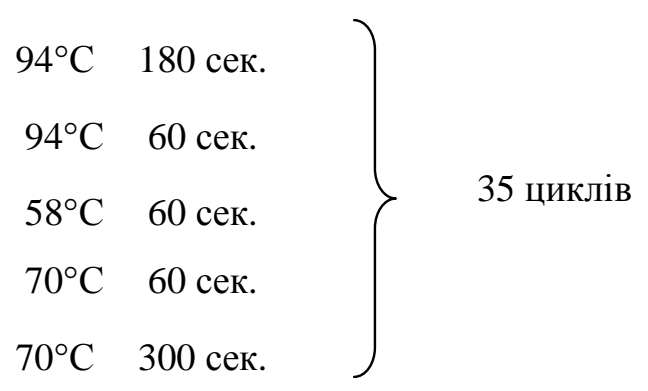

Ідентичність продукту ПЛР підтверджено шляхом рестрикційного аналізу з використанням ендонуклеази Alu I, в результаті якого утворилися два фрагменти ДНК із розміром 104 та 149 пар нуклеотидів.

Окрім того, розроблену нами ПЛР-тестсистему для індикації Chlamydia abortus, Chlamydia pecorum, Chlamydia psittaci було успішно випробувано на 50-и завідомо позитивних і 25-и завідомо негативних щодо хламідіозу зразках ДНК, виділених із біологічного матеріалу від свійських собак. Окрім того проведено валідацію 3 чотирма ПЛР-тест-системами для індикації ДНК бактерій роду Chlamydia, а саме: комерційно доступною ПЛР-тест-системою «ПОЛИМИК» (НПФ «Литех», Россия); двома ПЛР-тест-системами власного розроблення, праймери яких фланкують фрагменти ДНК генів, які кодують $16 \mathrm{~S}$ рРНК та MOMP бактерій роду Chlamydia патогенних для ссавців і птахів $[6,7]$; мультиплексною ПЛР-тестсистемою для диференціації збудників хламідіозу ссавців і птахів [8]. У результаті досліджень підтверджено аналітичну специфічність розробленої ПЛР-тест-системи для діагностики хламідійних інфекцій свійських собак. 


\section{ВЕТЕРИНАРНА МЕДИЦИНА}

Таким чином, вважаємо, що розроблена ПЛРтест-система може бути впроваджена у лабораторну практику для діагностики хламідійних інфекцій свійських собак.

\section{Висновки:}

1. Оскільки диференціюванням за видом ізолятів, виділених від 69 свійських собак, хворих на хламідіоз, за допомогою мультиплексної ПЛР-тест-системи власного розроблення встановлено, що вони є бактеріями порядку Chlamydiales, роду Chlamydia, видів Chlamydia abortus, Chlamydia pecorum та Chlamydia psittaci, дизайн олігонуклеотидних праймерів ПЛР-тест-системи для діагностики хламідіозу даного виду тварин підібрано на консервативну ділянку ДНК, що

\section{БІБЛІОГРАФІЯ}

1. Клінічні ознаки хламідіозу домашніх м'ясоїдних / В.В.Недосєков, О. Г. Мартинюк, I. М. Ксьонз [та ін.] // Ветеринарна медицина України. - 2010. - № 6. - С. 10-12.

2. Обухов И. Л. Обнаружение Chl. Psittaci при конъюнктивитах у собак / И. Л. Обухов // Сб. научн. трудов Всерос. гос. НИИ контроля стандартизации и сертификации вет. препаратов. - 1996. - T. 57. - C. 45-51.

3. Равилов Р. Х. Хламидиоз собак и кошек / Р. Х. Равилов. - М. : ООО «Аквариум-Принт», 2006. - $128 \mathrm{c}$.

4. Старченков С. Н. Заразные болезни собак и кошек. - СПб. : ООО «СПС», 2001. - 368 c.

5. Ксьонз I. М. Хламідіози тварин : [монографія] / Ксьонз Ігор Миколайович. - Полтава : Оріяна, 2012. - 318 с.

6. Пат. 34868 Україна, МПК А 61 К 39/118. Спосіб визначення ДНК семи збудників хламідійних інфекцій ссавців і птахів у одній поліме- кодує ген RNase P RNA означених трьох видів.

2. Ідентичність продукту ПЛР підтверджено шляхом рестрикційного аналізу з використанням ендонуклеази Alu I, в результаті якого утворилися два фрагменти ДНК із розміром 104 та 149 пар нуклеотидів.

3. Розроблена ПЛР-тест-система для діагностики хламідійних інфекцій у свійських собак пройшла успішні випробування на 75-и зразках ДНК, виділених із біологічного матеріалу, а також валідацію 3 іншими ПЛР-тест-системами для індикації та видової диференціації бактерій роду Chlamydia, i, відповідно, може використовуватися для діагностики хламідіозу цього виду домашніх м'ясоїдів.

разній ланцюговій реакції / I. М. Ксьонз, К. Ф. Почерняєв ; заявники і власники І. М. Ксьонз , К. Ф. Почерняєв ; заявл. 25.03.2008; опубл. 26.08.2008, Бюл. № 16.

7. Пат. 51635 Україна, МПК А 61 К 39/118. Спосіб визначення ДНК бактерій родини Chlamydiaceae у полімеразній ланцюговій реакції шляхом ампліфікації фрагменту гена головного білка мембрани (МОМР) / І. М. Ксьонз, К. Ф. Почерняєв; заявник і власник Полтавська дослідна станція Інституту ветеринарної медицини УААН; заявл. 19.01.2010; опубл. 26.07.2010, Бюл. №14.

8. Пат. 11834 Україна, МПК А 61 К 39/118. Спосіб визначення ДНК збудників хламідійних інфекцій у мультиплексній полімеразній ланцюговій реакції / I. М. Ксьонз, К. Ф. Почерняєв, А. Ф. Курман ; заявник і власник Полтавський філіал Інституту ветеринарної медицини УААН; заявл. 23.06.2005 ; опубл. 16.01.2006, Бюл. № 1. 